\title{
Effect of Plant Density on Morphological Characteristics, Yield and Chemical Composition of Napier Grass (Pennisetum purpureum (L.) Schumach)
}

\section{Tessema Zewdu}

Department of Animal Sciences, Haramaya Univesity, P O Box 188, Ethiopia

E-mail: tessemaz@yahoo.com

\begin{abstract}
An experiment to assess the effect of plant density on morphological characteristics, dry matter production and chemical composition of Napier grass (Pennisetum purpureum (L.) Schumach) was conducted in 2004 and 2005 at Haramaya University, eastern Ethiopia. There were a total of nine treatments with 1.5, 1 and $0.5 \mathrm{~m}$ spacing between rows and $0.75,0.5$ and $0.25 \mathrm{~m}$ spacing between plants, which consisted of $8,888.9$, $13,333.3,26,667.7,13,333.3,20,000,40,000,26,667.7,40,000$, and 80,000 plants per ha, arranged in a randomized complete block design with three replications. The plot size was $3 \mathrm{~m}$ width $\mathrm{x} 6 \mathrm{~m}$ length and the spacings between replications and plots were $1.5 \mathrm{~m}$ and $1 \mathrm{~m}$ respectively. There was no significant $(\mathrm{P}>0.05)$ effect in morphological characteristics of Napier grass due to plant density during the establishment year. However, the number of tillers, total leaves, internode number, internode length, basal circumference and leaf length per plant were significantly $(\mathrm{P}<0.05)$ affected by plant density in the second year. There was a significant $(\mathrm{P}<0.05)$ difference in dry matter (DM) yield due to plant density. A considerable variation in DM yield between the two years and number of harvests in each year was observed during the study and the DM yield in 2005 was much greater than the 2004 crop season. Higher DM yields were obtained from 80,000 (7.80 t/ha) and 40, 000 (39.9 t/ha) plant density in 2004 and 2005 respectively. There was no significant $(P>0.05)$ effect on the chemical composition of Napier grass due to plant density. However, the crude protein (CP) content of all the treatments was above 15\%, which is the optimum required for animal growth or production. The fibre fractions were also below the threshold level $(600 \mathrm{~g} / \mathrm{kg} \mathrm{DM})$ at which DM intake of cattle is affected. Based on DM yield production and CP content, the production of Napier grass using 40, 000 plants per hectare is recommended to livestock producers in eastern Ethiopia agro-ecologies of the country.
\end{abstract}

Keywords: Chemical Composition; Dry Matter Yield; Morphological Characteristics; Napier Grass; Plant Density

\section{Introduction}

The development of the livestock sub sector in Ethiopia is hindered by many constraints of which unavailability of both high quantity and quality feed is the major factor (Azage et al., 1995). More than $90 \%$ of livestock feed is crop residues and natural pasture in Ethiopia (Alemayehu, 2004), both of which are low in quantity and quality for sustaining animal production (Seyoum et al., 1998), resulting in slow growth rates, poor fertility and high rates of mortality (Osuji et al., 1993). The shortage of feed can be solved through the introduction and utilization of adaptable and high-yielding cultivated forage crops with better nutritional values than the existing feed resources in the country (Seyoum et al., 1998; Tessema and Halima, 1998).

Amongst the improved forage crops introduced in Ethiopia, Napier grass (Pennisetum purpureum (L.) Schumach) could play an important role in providing a significant amount of quality forage, both for the smallholder farmer as well as intensive livestock production systems with appropriate management practices (Alemayehu, 1997; Seyoum et al., 1998; Tessema and Halima, 1998; Alemayehu, 2002; 2004). Because of the importance of Napier grass in small-scale livestock farming enterprises, it is one of the most widely-used fodder crops among the livestock producers in Kenya (Annido and Potter, 1994; Kariuki et al., 1998), Pakistan (Butt et al., 1993), USA (Robert et al., 1995), Malaysia, Tanzania (Kidunda et al., 1990). It also performs well in the low, mid and highland areas of Ethiopia (Alemayehu, 1997; Seyoum et al., 1998; Tessema and Halima, 1998). It is superior to many other tropical grasses in terms of dry season growth and forage quality (Bayer, 1990) and can support a large number of animal units (Sollenberger et al., 1990) through the cut-and-carry system (Alemayehu, 1997; Kariuki et al., 1998).

Napier grass has been introduced in soil conservation areas, around homesteads, road-sides and livestock exclusion areas by smallholder farmers due to land shortages in Ethiopia. With appropriate management practices, Napier grass can provide a continual supply of green forage throughout the year and best suits intensive small-scale farming systems (Orodho, 1990; Alemayehu, 1997). The present study was therefore designed to assess the effect of different plant densities on the morphological characteristics, dry matter production and chemical composition of Napier grass in semi-arid areas of eastern Ethiopia where information is lacking.

\section{Material and Methods}

\subsection{Location, Treatment and Experimental Design}

The napier grass plant density experiment was conducted on alluvial-vertisols (Tamire, 1982) at Haramaya University Research Centre (9॰26’ N, 42。 03’ E; $2240 \mathrm{~m}$ a $\mathrm{s}$ 1). The $0-40 \mathrm{~cm}$ layer of the soil before fertiliser application had a $\mathrm{pH}$ of 6.34 , total $\mathrm{N}$ of 0.16 , available phosphorus level of $0.66 \mathrm{ppm}$, organic matter level of $2.28 \%$ and organic level carbon of $1.33 \%$. The twenty years mean annual rainfall for the area is $625 \mathrm{~mm}$ and the average annual air temperature is $20.15^{\circ} \mathrm{C}$. The monthly rainfall, number of rainy days, and the minimum and maximum air temperatures during the study are presented in Table 1. 
Table 1. Monthly total rainfall ( $\mathrm{mm}$ ), number of rainy days, and minimum and maximum air temperature during 20042005 at Haramaya, Ethiopia.

\begin{tabular}{|c|c|c|c|c|c|c|}
\hline \multirow{3}{*}{ Months } & & & \multicolumn{4}{|c|}{ Temperature $\left({ }^{0} \mathrm{c}\right)$} \\
\hline & \multicolumn{2}{|c|}{ Rainfall (mm) } & \multicolumn{2}{|c|}{ Mean maximum } & \multicolumn{2}{|c|}{ Mean minimum } \\
\hline & 2004 & 2005 & 2004 & 2005 & 2004 & 2005 \\
\hline January & 38.2 & 0.5 & 24.15 & 21.43 & 9.3 & 9.65 \\
\hline February & 0 & 2 & 23.95 & 24.26 & 5.85 & 6.25 \\
\hline March & 25.4 & 39.9 & 25.65 & 24.45 & 8.85 & 8.76 \\
\hline April & 163.5 & 119.5 & 23.9 & 25.7 & 14.2 & 13.5 \\
\hline May & 39.5 & 198.3 & 26.45 & 23.7 & 11.7 & 12.5 \\
\hline June & 25.5 & 19.2 & 24.75 & 25 & 14.1 & 14.4 \\
\hline July & 71.32 & 68.1 & 24 & 23 & 13.3 & 13.2 \\
\hline August & 116.4 & 126.2 & 24.5 & 24 & 13.6 & 13.5 \\
\hline September & 126.7 & 156.4 & 24 & 23 & 12.1 & 12.5 \\
\hline October & 43.8 & 17 & 25.04 & 23.1 & 6.45 & 11.2 \\
\hline November & 38.6 & 33.6 & 24.7 & 23.7 & 5.5 & 7.9 \\
\hline December & 4.5 & 0 & 21.43 & 22.4 & 4.0 & 6.1 \\
\hline
\end{tabular}

The study was conducted in a randomised complete block design with three replications on a plot size of $3 \mathrm{~m}$ (width) by $6 \mathrm{~m}$ (length). The spacings between replications and plots were $1.5 \mathrm{~m}$ and $1 \mathrm{~m}$, respectively. The treatments consisted of plant spacing of: 26,666.7 $(1.5 \mathrm{~m}$ row $\mathrm{x} 0.25 \mathrm{~m}), 40,000(1.0 \mathrm{~m}$ row $\mathrm{x} 0.25 \mathrm{~m}), 80,000$
$(0.5 \mathrm{~m}$ row $\times 0.25 \mathrm{~m}), 13,333.3(1.5 \mathrm{~m}$ row $\mathrm{x} 0.5 \mathrm{~m}), 20,000$ $(1.0 \mathrm{~m}$ row $\times 0.5 \mathrm{~m}), 40,000(0.5 \mathrm{~m}$ row $\mathrm{x} 0.5 \mathrm{~m}), 8,888.9$ $(1.5 \mathrm{~m}$ row $\times 0.75 \mathrm{~m}), 13,333.3(1.0 \mathrm{~m}$ row $\times 0.75 \mathrm{~m})$ and $26,667.7$ ( $0.5 \mathrm{~m}$ row $\mathrm{x} 0.75 \mathrm{~m})$ plants per hectare. The treatment structure of the experiment is presented in Table 2.

Table 2. Row and plant spacing structures of the treatments during the experimental periods.

\begin{tabular}{llll}
\hline Row spacing $(\mathrm{m})$ & Plant spacing $(\mathrm{m})$ & Area/plant $\left(\mathrm{m}^{2}\right)$ & Number of plants $/$ ha \\
\hline 1.5 & 0.25 & $1.5 \mathrm{~m} \times 0.25 \mathrm{~m}=0.375$ & $26,666.7$ \\
1 & 0.25 & $1.0 \mathrm{~m} \times 0.25 \mathrm{~m}=0.25$ & 40,000 \\
0.5 & 0.25 & $0.5 \mathrm{~m} \times 0.25 \mathrm{~m}=0.125$ & 80,000 \\
1.5 & 0.5 & $1.5 \mathrm{~m} \times 0.5 \mathrm{~m}=0.75$ & $13,333.3$ \\
1 & 0.5 & $1.0 \mathrm{~m} \times 0.5 \mathrm{~m}=0.50$ & 20,000 \\
0.5 & 0.5 & $0.5 \mathrm{~m} \times 0.5 \mathrm{~m}=0.25$ & 40,000 \\
1.5 & 0.75 & $1.5 \mathrm{~m} \times 0.75 \mathrm{~m}=1.125$ & $8,888.9$ \\
1 & 0.75 & $1.0 \mathrm{~m} \times 0.75 \mathrm{~m}=0.75$ & $13,333.3$ \\
0.5 & 0.75 & $0.5 \mathrm{~m} \times 0.75 \mathrm{~m}=0.375$ & $26,667.7$ \\
\hline
\end{tabular}

2.2. Establishment and Management of Napier Grass High-yielding and adaptable Napier grass accession (ILRI No. 16791) was vegetatively propagated using uniform root splits on well-prepared soil under rainfed conditions in the last week of July 2004 when the soil was moist. Diammonium phosphate was applied at planting at 100 $\mathrm{kg} \mathrm{ha} \mathrm{k}^{-1}$ for establishment and urea at $50 \mathrm{~kg} \mathrm{ha}^{-1}$ was applied after establishment as recommended (IAR, 1988). In the second year, the same amount of urea was applied at the start of the main rainfall after uniform cutting of all the plots at the same time.

\subsection{Data Collection and Analytical Procedures}

Vigour was rated visually on the scale of $1=$ poor to $5=$ excellent. Three plants in each treatment were randomly selected to record number of tiller per plant (NTPP), basal circumference per plant (BCPP), total number of leaves per plant (TLPP), internode number per plant (INPP), leaf length per plant (LLPP) and leaf: stem ratio (LSR). Two tillers from each randomly-taken plant were used to determine the number of leaves per tiller (NLPT) (Butt et al., 1993; Tessema, 2000; Tessema et al., 2003).
Napier grass was harvested about $10-15 \mathrm{~cm}$ above the ground from all the treatments, excluding border rows, and all harvested samples from each plot were thoroughly mixed and $250 \mathrm{~g}$ was taken for dry matter (DM) yield determination by drying at $65^{\circ} \mathrm{C}$ for $72 \mathrm{~h}$ (constant weight). Harvests were made 2 and 3 times in 2004 and 2005 respectively when the plant height reached $1 \mathrm{~m}$. Representative whole plants from each treatment were oven-dried, ground to pass through a $1 \mathrm{~mm}$ sieve and stored in airtight containers for different chemical analyses. Ash was determined by igniting at $550{ }^{\circ} \mathrm{C}$ overnight, total $\mathrm{DM}$ by drying at $105^{\circ} \mathrm{C}$ and $\mathrm{N}$ by autoanalyser (Chemlab, 1984). Crude protein (CP) was calculated as $\mathrm{N} \times$ 6.25. Neutral detergent fibre (NDF), acid detergent fibre (ADF) and acid detergent lignin (ADL) were determined according to Goering and Van Soest (1970). Hemicellulose and cellulose were calculated as NDF - ADF and ADF - ADL respectively. All the chemical analyses were done in duplicate (at the Haramaya University Animal Nutrition Laboratory.) to increase precision. 


\subsection{Statistical Analysis}

Analysis of variance was carried out using the SAS (1998) General Linear Models' procedure and applied to randomized complete block design and mean separation was tested by least significant difference (LSD).
3. Results and Discussion

\subsection{Morphological Characteristics}

There was no significant $(\mathrm{P}>0.05)$ effect in morphological characteristics of Napier grass due to plant density during the establishment year (Table 3). However, NTPP, TLPP, INPP, ILPP, BCPP and LLPP were significantly $(\mathrm{P}<0.05)$ affected by different plant density in the second year (Table 4).

Table 3. Morphological characteristics of Napier grass as influenced by different plant populations during the establishment year.

\begin{tabular}{|c|c|c|c|c|c|c|c|c|}
\hline \multirow[t]{2}{*}{ Plant population } & \multicolumn{3}{|c|}{ Morphological characteristics } & \multirow[b]{2}{*}{ TLPP } & \multirow[b]{2}{*}{ INPP } & \multirow[b]{2}{*}{ BCPP } & \multirow[b]{2}{*}{ ILPP } & \multirow[b]{2}{*}{ LSR } \\
\hline & Vigor & NTPP & NLPT & & & & & \\
\hline $26,666.7$ & 5.00 & 22.27 & 11.00 & 244.64 & 6.00 & 70.67 & 7.67 & 1.24 \\
\hline 40,000 & 5.00 & 25.53 & 11.73 & 264.76 & 5.67 & 65.00 & 6.33 & 0.98 \\
\hline 80,000 & 5.00 & 20.67 & 12.33 & 252.77 & 6.00 & 64.33 & 8.23 & 1.07 \\
\hline $13,333.3$ & 4.00 & 18.93 & 11.33 & 216.03 & 4.67 & 58.67 & 6.17 & 1.08 \\
\hline 20,000 & 4.67 & 24.20 & 10.80 & 257.04 & 4.33 & 48.33 & 5.60 & 1.08 \\
\hline 40,000 & 5.00 & 20.80 & 11.53 & 239.21 & 4.67 & 51.67 & 5.40 & 1.41 \\
\hline $8,888.9$ & 4.33 & 24.13 & 10.00 & 236.21 & 4.67 & 61.00 & 4.97 & 0.93 \\
\hline $13,333.3$ & 3.33 & 18.80 & 11.27 & 206.21 & 4.67 & 54.67 & 7.03 & 1.30 \\
\hline $26,667.7$ & 5.00 & 20.40 & 11.27 & 229.33 & 5.00 & 64.00 & 7.80 & 1.11 \\
\hline Mean & 4.59 & 21.75 & 11.25 & 238.50 & 5.07 & 59.82 & 6.58 & 1.13 \\
\hline s.e. & 0.35 & 2.31 & 0.72 & 33.83 & 0.64 & 7.13 & 1.65 & 0.20 \\
\hline P level & $*$ & NS & NS & NS & NS & NS & NS & NS \\
\hline
\end{tabular}

Table 4. Morphological characteristics of Napier grass as influenced by different plant populations during the second year of establishment.

\begin{tabular}{|c|c|c|c|c|c|c|c|c|c|}
\hline \multirow[b]{2}{*}{ Plant population } & \multicolumn{3}{|c|}{ Morphological characteristics } & \multirow[b]{2}{*}{ INPT } & \multirow[b]{2}{*}{ INPP } & \multirow[b]{2}{*}{ ILPT } & \multirow[b]{2}{*}{ ВCPP } & \multirow[b]{2}{*}{ LL } & \multirow[b]{2}{*}{ LSR } \\
\hline & $\begin{array}{c}\text { NTP } \\
\text { P }\end{array}$ & NLPT & TLPP & & & & & & \\
\hline $26,666.7$ & 62.3 & 15.3 & 955.5 & 10.3 & 637.0 & 14.3 & 198.7 & 116.7 & 1.02 \\
\hline 40,000 & 35.0 & 15.0 & 525.0 & 9.7 & 372.0 & 15.7 & 153.3 & 120.7 & 0.94 \\
\hline 80,000 & 36.0 & 14.7 & 528.1 & 10.3 & 381.3 & 17.3 & 167.7 & 127.0 & 1.00 \\
\hline $13,333.3$ & 38.3 & 13.3 & 510.9 & 8.0 & 297.7 & 17.3 & 160.7 & 121.0 & 0.95 \\
\hline 20,000 & 29.7 & 14.0 & 415.5 & 10.0 & 297.0 & 15.7 & 125.3 & 125.7 & 1.09 \\
\hline 40,000 & 22.7 & 14.0 & 317.4 & 8.3 & 176.3 & 16.0 & 126.7 & 126.7 & 1.12 \\
\hline $8,888.9$ & 59.3 & 15.0 & 890.0 & 10.0 & 596.7 & 19.0 & 191.3 & 121.7 & 0.95 \\
\hline $13,333.3$ & 32.0 & 14.0 & 448.0 & 9.0 & 289.3 & 16.0 & 141.7 & 121.3 & 0.90 \\
\hline $26,667.7$ & 24.3 & 14.0 & 340.6 & 8.3 & 200.3 & 17.7 & 125.0 & 128.3 & 1.01 \\
\hline Mean & 37.74 & 14.47 & 547.9 & 9.33 & 360.9 & 16.6 & 154.6 & 123.2 & 1.00 \\
\hline s.e. & 6.97 & 1.02 & 114.0 & 1.36 & 102.1 & 0.98 & 17.7 & 2.51 & 0.06 \\
\hline P level & $* *$ & NS & ** & NS & $*$ & $*$ & $*$ & $*$ & NS \\
\hline
\end{tabular}

The highest NTPP (62.3), INPT (10.3), TLPP (955.5) and BCPP $(198.6 \mathrm{~cm})$ were obtained from 26,666.7 plants per hectare. High morphological characteristic values of Napier grass were observed from medium and lower plant density compared to higher plant density per hectare during the study. This might be due to the fact that plants with wider spacing produced many finestemmed tillers and showed with vigorous growth and development and leafy structures because of reduced competition for space, moisture and nutrients during the growing period as reported by Wilson et al. (1989).

The general trend of LSR increased as the spacing between plants and rows increased in Bana grass (Berihun, 2005). Napier grass planted at $50 \mathrm{~cm} \times 50 \mathrm{~cm}$ spacing produced 1.49 leaf to stem ratio (Taye, 2004) compared to plant spacing of $100 \mathrm{~cm} \times 50 \mathrm{~cm}$ with 1.91 LSR (Tessema, 2000; Tessema et al., 2003). Narrow spacing resulted in a higher number and longer internodes than wider spacing (Singh and Singh, 1971) and the 
tillering capacity increased with their relative increase in plant spacing. The maximum tillers in Mott Napier grass were recorded in spacing of $120 \mathrm{~cm} \times 120 \mathrm{~cm}$ followed by $105 \mathrm{~cm} \times 105 \mathrm{~cm}$ against the minimum tillers count in a spacing of $45 \mathrm{~cm} \times 45 \mathrm{~cm}$ (Yasin et al., 2003). Khan and Manghatt (1965) on pearl millet (Pennisetum typhoides) reported that the number of tillers increased consistently with an increase in plant spacing. Leaves' expansions from narrow spacing were smaller in length compared to those from wider spacing (Begna et al., 2000).

\subsection{Dry Matter Production}

There was a significant $(\mathrm{P}<0.05)$ difference in DM yield among the different plant densities in Napier grass (Table 5). Higher total DM yields were obtained from 80,000 $(7.80 \mathrm{t} / \mathrm{ha})$ and 40, $000(39.9 \mathrm{t} / \mathrm{ha})$ in 2004 and $2005 \mathrm{crop}$ seasons respectively. There was also a considerable variation in DM yield between the two years and number of harvests in each year (Tables 5,6).

Table 5. Dry matter production of Napier grass as influenced by different plant populations.

\begin{tabular}{|c|c|c|c|c|c|c|c|c|c|c|c|c|}
\hline \multirow{3}{*}{$\begin{array}{c}\text { Plant } \\
\text { population }\end{array}$} & \multicolumn{12}{|c|}{ Dry matter yield (t/ha) } \\
\hline & \multicolumn{5}{|c|}{ 2004/05 harvest } & \multicolumn{6}{|c|}{ 2005/06 harvests } & \multirow[t]{2}{*}{ Mean } \\
\hline & $1^{\text {st }}$ & $2^{\text {nd }}$ & Total & LDM & SDM & $1^{\mathrm{st}}$ & $2^{\text {nd }}$ & $3^{\text {rd }}$ & Total & LDM & SDM & \\
\hline $26,666.7$ & 4.1 & 2.0 & 6.1 & 3.4 & 2.8 & 20.2 & 17.9 & 0.8 & 38.9 & 19.8 & 19.1 & 22.5 \\
\hline 40,000 & 4.27 & 1.7 & 5.9 & 2.9 & 3.0 & 22.0 & 15.8 & 0.9 & 38.7 & 19.0 & 19.7 & 22.3 \\
\hline 80,000 & 5.9 & 1.9 & 7.8 & 4.0 & 3.5 & 17.6 & 14.5 & 1.0 & 33.16 & 16.4 & 16.7 & 20.4 \\
\hline $13,333.3$ & 3.2 & 1.3 & 4.6 & 2.4 & 2.2 & 14.9 & 15.6 & 0.6 & 31.0 & 15.3 & 15.7 & 17.8 \\
\hline 20,000 & 3.1 & 1.3 & 4.4 & 2.2 & 2.2 & 17.3 & 16.9 & 0.9 & 34.9 & 18.4 & 16.5 & 19.7 \\
\hline 40,000 & 4.2 & 1.9 & 6.1 & 3.5 & 2.6 & 24.0 & 15.1 & 0.9 & 39.9 & 21.1 & 18.8 & 23.0 \\
\hline $8,888.9$ & 3.0 & 1.7 & 4.5 & 2.1 & 2.7 & 12.6 & 22.9 & 0.7 & 36.2 & 18.2 & 16.1 & 20.5 \\
\hline $13,333.3$ & 2.3 & 1.6 & 3.9 & 2.1 & 1.9 & 20.5 & 18.8 & 0.8 & 40.0 & 19.2 & 20.8 & 22.0 \\
\hline $26,667.7$ & 3.6 & 1.6 & 5.2 & 2.7 & 2.3 & 18.2 & 18.6 & 0.9 & 37.7 & 18.7 & 19.0 & 21.5 \\
\hline Mean & 3.8 & 1.7 & 5.4 & 2.8 & 2.6 & 18.6 & 17.4 & 0.9 & 36.7 & 18.5 & 18.36 & 21.2 \\
\hline s.e. & 0.67 & 0.23 & 0.82 & 0.43 & 0.50 & 1.54 & 2.56 & 0.104 & 2.86 & 1.53 & 1.33 & 1.98 \\
\hline P level & $*$ & NS & $*$ & $*$ & NS & $* *$ & $*$ & NS & $*$ & $* *$ & $* *$ & NS \\
\hline
\end{tabular}

Table 6. The combined analysis of variance (ANOVA) for Napier grass plant density experiments over the years (20042005).

\begin{tabular}{llllll}
\hline Source of variation & $\begin{array}{l}\text { Degrees of } \\
\text { freedom }\end{array}$ & Sum of squares & Mean squares & F calculated & Probability \\
\hline Replication & 2 & 419.208 & 209.602 & 8.8740 & 0.0008 \\
Year & 1 & 13215.926 & 13215.926 & 559.5214 & 0.0000 \\
Treatment & 8 & 129.686 & 16.211 & 0.6863 & \\
Treatment x Year & 8 & 143.214 & 17.902 & 0.7579 \\
Error & 34 & 803.082 & 23.620 & & \\
\hline Total & 53 & 14711.116 & & & \\
\hline
\end{tabular}

The DM yield in 2005 was much greater than in the 2004 crop season. This might be due to the perennial nature of Napier grass, which produces more tillers and high vegetative growth as the pasture period increases, as reported by Tessema (2005) and Ndikumana (1996) from tests on different Napier grass accessions in the north western parts of Ethiopia and many African countries. In addition, the number of harvests taken in the 2005 crop season was three but only two harvests were taken in 2004 since it was the year of Napier grass establishment. The DM yield of the first harvest was higher than the second or third harvests in each year because of the fact that the first harvest was taken during the rainy season where rainfall was sufficient for growth, while the second and third harvests were taken in the early and late dry seasons respectively which might have resulted in reduced DM yield production.
The present findings are similar to those of Berihun (2005) who reported that there was a significant $(\mathrm{P}<$ 0.05 ) effect on DM yield of Bana grass due to plant density in semiarid areas of north-western Ethiopia. However, the same author reported a non-significant $(\mathrm{P}$ $>0.05)$ effect on the combined DM yield of Napier grass due to plant density. The effect of plant density in Napier grass was enhanced in the year of establishment and in the dry seasons, contrary to the subsequent years and in rainy seasons and, consequently, the overall effect of plant density on long-term average annual yields was negligible (Boonman, 1993). In addition, most trials with plant density varying from $3333(300 \mathrm{~cm} \times 100 \mathrm{~cm})$ to 20,000 plants $(100 \mathrm{~cm} \times 50 \mathrm{~cm})$ gave almost identical herbage yields when totalled over wet and dry seasons for a number of years in Kenya, as indicated by Boonman (1993). Low plant density or wider spacing made an 
enormous difference to the rate of plant growth and yield performances, clumps expansion and filling for continuous growth within the rows compared to narrow spacing (Boonman, 1993). Dry matter yield increased as plant density increased. However, narrower row spacing may facilitate stand establishment and increase forage production in the early life of the pasture sward. Saeed et al., (1996) on Mott Napier grass reported that close spacing produced higher productivity than wider plant spacing after establishment.

\subsection{Chemical Composition}

There was no significant $(\mathrm{P}>0.05)$ effect on the chemical composition of Napier grass due to plant density during the study (Table 7). However, Berihun (2005) reported that the combination of row and plant spacing affected the CP, NDF, ADF, ADL, Ca, P and IVDMD values of Bana grass in semiarid areas of north western Ethiopia but a significant effect was not reported on cellulose and hemicellulose contents due to plant density (Berihun, 2005). This might be due to the fact that all the plant materials used in the study were from the same genetic accession and all the treatments were harvested at the same growth stage. Many research reports revealed that plant height at cutting (Tessema, 2000; Tessema et al., 2002a; 2002b; 2003), stage of growth (McDonald et al., 1988; Seyoum et al., 1998; Tessema et al., 2002a; Tessema and Baars 2003; Taye 2004; Berihun, 2005) and varietal difference (Ndikumana, 1996; Seyoum et al., 1998 and Tessema, 2005) are the major factors that affect the chemical composition and digestibility of Napier grass.

Plant density did not show any significant effect on the chemical composition of Napier grass in the study; however, the CP content of all the treatments was above the minimum CP level of $75 \mathrm{~g} / \mathrm{kg}$ required for adequate rumen function in ruminants (van Soest, 1984). The minimum CP content required for lactation and growth of cattle is $150 \mathrm{~g} / \mathrm{kg}$ (Norton, 1982), suggesting that all the treatments were above the recommendation (range $158.3-171.8 \mathrm{~g} / \mathrm{kg}$ ) and would satisfy the production requirement of ruminants. The threshold level of NDF in tropical grass beyond which DM intake of cattle is affected is $600 \mathrm{~g} / \mathrm{kg}$ (Meissner et al., 1991), suggesting that all the treatments have a lower value than this (range $533.4-554.5 \mathrm{~g} / \mathrm{kg}$ ). In the study, the cellulose (range 256.7-271.7 g/ kg) and hemicellulose (range 237.4-253.0 $\mathrm{g} / \mathrm{kg}$ ) contents of the treatments were lower than those of most tropical grasses, 319 and $354 \mathrm{~g} / \mathrm{kg}$ respectively (Moore and Hatfield, 1994).

Table 7. Chemical composition of Napier grass as influenced by different plant populations.

\begin{tabular}{|c|c|c|c|c|c|c|c|c|c|c|}
\hline \multirow{2}{*}{$\begin{array}{c}\text { Plant } \\
\text { Population }\end{array}$} & \multicolumn{10}{|c|}{ Chemical compositions (\% DM basis) } \\
\hline & $\mathrm{DM}$ & $\mathrm{CP}$ & NDF & TA & $\mathrm{ADF}$ & ADL & Cellul & $\begin{array}{c}\text { Hemi } \\
\text { cel }\end{array}$ & SS & BS \\
\hline $26,666.7$ & 96.63 & 15.83 & 54.49 & 15.04 & 29.44 & 3.60 & 25.86 & 25.06 & 2.24 & 1.88 \\
\hline 40,000 & 96.27 & 16.12 & 54.93 & 14.68 & 29.64 & 3.33 & 26.31 & 25.30 & 2.06 & 1.81 \\
\hline 80,000 & 95.57 & 15.46 & 55.45 & 14.64 & 31.09 & 3.91 & 27.17 & 24.36 & 1.66 & 2.05 \\
\hline $13,333.3$ & 96.07 & 16.62 & 54.68 & 15.56 & 29.54 & 3.74 & 25.80 & 25.14 & 2.62 & 1.93 \\
\hline 20,000 & 95.10 & 17.18 & 53.98 & 14.63 & 29.39 & 3.57 & 25.81 & 24.60 & 2.47 & 1.73 \\
\hline 40,000 & 95.90 & 16.39 & 54.97 & 15.23 & 29.79 & 4.12 & 25.67 & 25.18 & 2.44 & 2.09 \\
\hline $8,888.9$ & 96.13 & 16.21 & 54.56 & 14.72 & 26.62 & 3.06 & 26.55 & 24.94 & 1.99 & 1.92 \\
\hline $13,333.3$ & 96.67 & 17.06 & 53.61 & 14.85 & 29.87 & 3.50 & 26.37 & 23.74 & 2.49 & 1.73 \\
\hline $26,667.7$ & 96.13 & 16.74 & 53.34 & 15.07 & 29.91 & 3.58 & 26.33 & 23.43 & 2.33 & 2.20 \\
\hline Mean & 96.05 & 16.40 & 54.45 & 14.94 & 29.81 & 3.60 & 26.21 & 24.64 & 2.26 & 1.93 \\
\hline s.e. & 0.52 & 0.54 & 0.83 & 0.56 & 0.59 & 0.33 & 0.50 & 0.62 & 0.29 & 0.40 \\
\hline P level & NS & NS & NS & NS & NS & NS & NS & NS & NS & NS \\
\hline
\end{tabular}

\section{Conclusions}

In conclusion, there was no significant effect on the morphological characteristics of Napier grass due to plant density during the establishment year. However, NTPP, TLPP, INPP, ILPP, BCPP and LLPP were significantly affected by plant density in the second year. There was a significant difference in DM yield among different plant densities in Napier grass over the two seasons' study period. Higher DM yields were obtained from 80,000 and 46, 667 in the 2004 and 2005 crop seasons respectively. There was no significant effect on the chemical composition of Napier grass due to plant density during the study. However, the CP content of all the treatments was above the minimum CP level of $75 \mathrm{~g} / \mathrm{kg}$ required for adequate rumen function in ruminants and the fibre fractions were below the threshold level at which DM intake of cattle is affected. Based on DM yield production and CP content, the planting of Napier grass using 40, 000 plants per hectare on $0.25 \mathrm{~m}^{2}$ area/plant; i.e. $1 \mathrm{~m} \mathrm{x}$ $0.25 \mathrm{~m}$ or $0.5 \mathrm{~m} \times 0.5 \mathrm{~m}$ would be advantageous to the smallholder farmers (in the semiarid areas of Ethiopia and in similar agro-ecologies of the country.) instead of large areas per $\mathrm{m}^{2}$. Moreover, further studies on the economics of plant density are recommended as a means of achieving least-cost Napier grass pasture production in smallholder conditions in the semiarid areas of Ethiopia and other similar areas.

\section{Acknowledgements}

The author would like to acknowledge the Haramaya University (HU) Research and Extension Office and the Ethiopian Agricultural Research Institute (EARI), for 
financing the research. All staff of the Animal Nutrition Laboratory of $\mathrm{HU}$ are gratefully acknowledged for their assistance during the chemical analysis.

\section{References}

Alemayehu, M. 1997. Conservation based forage development for Ethiopia. Self Help Development International and Institute for Sustainable Development Publishers. Addis Ababa, Ethiopia.

Alemayehu, M. 2002. Forage production in Ethiopia. A case study with implications for livestock production. Ethiopian Society of Animal Production, Addis Ababa, Ethiopia.

Alemayehu, M. 2004. Pasture and forage resource profiles of Ethiopia. EDM printing Press, Addis Ababa, Ethiopia.

Annido, D. O. and Potter, H. L. 1994. Seasonal variation in productivity and nutritive value of Napier grass at Muguga, Kenya. East African Agricultural Forestry Journal 59: 177-195.

Azage, T., Lahlou-Kassi, A. and Mukassa-Mugerewa, E. 1995. Biotechnology in animal production. In: development opportunities in livestock agriculture. Proceedings of the Second National Conference of the Ethiopian Society of Animal Production (ESAP), Addis Ababa, ESAP, 26-27 May 1995. pp: 49-80.

Bayer, W. 1990. Napier grass: a promising fodder for small holder livestock production in the tropics. Plant research and development 31:103-101.

Begna, S.H., Hamilton, R.I., Dwyer, L.M., Stewart, D.W. and Smith, D.I. 2000. Variability among maize hybrids differing in canopy architecture for aboveground dry matter and grain yield. Maydica. 45: 135-141.

Berihun, M. 2005. Effect of planting patterns and harvesting days on yield and quality of Bana grass [Pennisetum Purpureum (L.) x Pennisetum Americanum (L.)]. MSc Thesis, Haramaya University, Haramaya, Ethiopia.

Boonman, J.G. 1993. East Africa's grasses and fodders: Their ecology and husbandry. Kluwer Academic Publishes, The Netherlands.

Butt, N. M., Donart, G.B., Southward, M. G. Pieper, R. D and Mohammad, N. 1993. Effect of defoliation on plant growth of Napier grass. Tropical Science 33: 101 120.

Chemlab. 1984. Continuous flow analysis system 40 . Method Sheet No. CW2-008-17 (Ammonia (0-1 and 0-50 PPM. N). Chemlab Instruments Ltd, UK.

Goering, H.K. and Van Soest, P.J. 1970. Forage fiber analysis (apparatus, reagents and some applications). Agricultural handbook No. 379. Agricultural Research Services, USA.

IAR. 1988. Handbook on forage and pasture crops for feeding animals. Institute of Agricultural Research. Addis Ababa, Ethiopia.

Kariuki, J. N., Gitau, G. K., Tamminga, S., Van Bruchem, J., Muia, J. M. K. and Jrunga, K.R.G. 1998. Effect of feeding napier grass, lucerne and sweet potato vines as sole diets to dairy. heifers on nutrient intake, weight gain and rumen degradation. Livestock Production Science 55: 12-20.
Khan, R.A. and Manghatt, M.A. 1965. Spacing experiments with Bajra Napier grass. Pakistan Journal of Agricultural Science 11: 49-50.

Kidunda, R.S., Lwoga, A.B. and Mtengeti, E.J. 1990. Utilization of Pasture Research Results in Tanzania. PANESA/ARNAB (Pastures Network for Eastern and Southern Africa/African Research network for Agricultural By-products). Utilization of research results on forage and agricultural by-products materials as animal feed resources in Africa. Proceedings of the first joint workshop held in Lilongwe, Malawi. 5-9 December 1999. PANESA/ARNAB, Addis Ababa, Ethiopia. PP. 705-735.

McDonald, P., Edwards, R.A., Greenhalgh, J.F.D. 1988. Animal Nutrition. $4^{\text {th }}$ edition, Longman Group UK Ltd., England.

Meissner, H.H., Koster, H.H., Nieuwoudt, S.H. and Coetze, R.J. 1991. Effects of energy supplementation on intake and digestion of early and mid-season ryegrass and Panicum/Smuts finger hay, and on in sacco disappearance of various forage species. South African Journal of Animal Science 21: 33-42.

Moore, K.J. and Hatfield, R.D. 1994. Carbohydrates and forage quality. In: George, C., Fahey, Jr., Michael, C. D., Mertens, R. and Moser, E. (eds.) Forage quality, evaluation and utilization. American Society of Agronomy Inc., Crop Science of America Inc and Soil Science Society of America Inc., Madison. pp. 229-280

Ndikumana, J. 1996. Multi-locational evaluation of Napier and Pennisetum hybrids: Highlights of from the Addis Ababa. AFRNET newsletter 6, 1-11.

Norton, B. W. 1982. Differences between species in forage quality. In: Proceedings of international symposium held at St. Luica, Queeensland, Australia. 24-29 Sep. 1981. Nutritional limits to animal production from pastures.

Orodho, A.B. 1990. Dissemination and utilization of research technology on forages and agricultural byproducts in Kenya. PANESA/ARNAB (Pastures Network for Eastern and Southern Africa/African Research network for Agricultural By-products). Utilization of research results on forage and agricultural by-products materials as animal feed resources in Africa. Proceedings of the first joint workshop held in Lilongwe, Malawi. 5-9 Dec., 1999, PANESA/ARNAB, Addis Ababa, Ethiopia. pp. 705735.

Osuji, P.O., Nsahlai, I.V. and Khalili, H. 1993. Feed Evaluation. ILCA Manual 5. International Livestock Centre for Africa, Addis Ababa, Ethiopia. pp. 40.

Robert, F. B., Miller, D. A. and Jerry Nelson, C. 1995. Forages (5 $5^{\text {th }}$ Eds.) Volume I. An introudction to grassland agriculture. Iowa state university press, Ames, Iowa.

Saeed, M., Siddiqui, N.A., Maqsood, M. and Mahmood, T. 1996. Effect of nitrogen and plant spacing on growth, green fodder yield and quality of Mott Elephant grass (Pennisetum purpureum). Pakistan Journal of Science Ind. Research 39: 54-59. 
SAS. 1998. SAS/STAT version 7. Guide to Personal Computers-Version 7. USA: Statistical Analysis System Institute Inc.

Seyoum, B., Zinashi, S., Tadesse, T.T. and Liyusew, A. 1998. Evaluation of Napier (Pennisetum purpureum) and pennisetum hybrids (Pennisetum purpureum $\mathrm{x}$ pennisetum typhoides) in the Central Highlands of Ethiopia. In: Proceedings of the Fifth Conference of Ethiopian Society of Animal Production (ESAP). 1417 May 1997. Addis Ababa, Ethiopia. pp. 194-202.

Singh, R. and Singh, S.N. 1971. Effect of different plant spacing and nitrogen fertilization on the agronomic characters and yield of finger millet. Indian Journal of Agricultural Science 41: 336-339.

Sollenberger, L.C., Jones, Jr., Albrecht, K.A. and Ruitenberg, G.H. 1990. Vegetative establishment of Dwarf Elephant grass. Effect of defoliation prior to planting stems. Agronomy Journal 92: 274-279.

Tamire, H. 1982. Summary of results of soil research programme in Hararghe highlands, eastern Ethiopia. Department of Plant Sciences, College of Agriculture, Addis Ababa University, Ethiopia.

Taye, B. 2004. Effect of intercropping Napier grass with Desmodim intortum or Lablab purpureus on forage yield and nutritional quality. MSc Thesis, Haramaya University, Haramaya, Ethiopia.

Tessema, Z. and Halima, H. 1998. Review of forage and pasture crops research achievements in northwestern Ethiopia. In: Beyene, S. and Aberra, D.(eds.). Agricultural Research and Technology Transfer Attempts and Achievements in Northern Ethiopia. Proceedings of the Fourth Technology Generation, Transfer and Gap Analysis Workshop. 19-21 March 1997, Bahir Dar, Ethiopia. pp. 62-69.

Tessema, Z. 2000. Productivity, chemical composition and digestibility of elephant grass (Pennisetum purpureum (L.) Schumach.) as influenced by height of harvesting and different sources of fertilizer application. MSc Thesis, Haramaya University, Haramaya, Ethiopia.
Tessema, Z., Baars, R.M.T., Alemu, Y. and Dawit, N. 2002a. Sacco dry matter and nitrogen degradation and their relationship with in vitro dry matter digestibility of Napier grass (Pennisetum purpureum Schumach.) as influenced by plant height at cutting. Australian Journal of Agricultural Research 53: 7-12.

Tessema, Z., Baars, R.M.T. and Alemu, Y. 2002b. Effect of plant height at cutting, source and level of fertilizer on yield and nutritional quality of Napier grass (Pennisetum purpureum Schumach.). African Journal of Range and Forage Science 19: 123-129.

Tessema, Z., Baars, R.M.T. and Alemu, Y. 2003. Effect of plant height at cutting and fertiliser on growth of Napier grass (Pennisetum purpureum Schumach.). Tropical Science 43: 57-61.

Tessema, Z. and Baars, R.M.T. 2003. Effect of cutting height of Napier grass on rumen degradation and invitro dry matter digestibility. Tropical Science 43: 125121.

Tessema, Z. 2005. Variation in growth, yield, chemical composition and in vitro dry matter digestibility of Napier grass accessions (Pennisetum purpureum). Tropical Science 45: 93-99.

Van Soest, P.J. 1982. Nutritional ecology of ruminants. O and B Books Inc., Corvallis, OR.

Wilson, J.R., Anderson, K.L. and Hackor, J.B. 1989. Dry matter digestibility in vitro of leaf and stem of buffel grass (Cenchrus cillaris) and related species and its relation to plant morphology and anatomy. Australian Journal of Agricultural Research 40: 281-291.

Yasin, M., Malik, M.A. and Nazir, M.S. 2003. Effect of different spatial arrangement on forage yield, yield components and quality of Mott Elephant grass. Pakistan Journal of Agronomy 2: 52-58. 